\title{
NVMO-congres 2007
}

\section{BSL-prijzen opnieuw toegekend}

De uitgever Bohn Stafleu van Loghum gaf de NVMO dit jaar de mogelijkheid vier prijzen toe te kennen op het congres: voor de beste wetenschappelijke paper, de beste onderzoekspaper, de beste paper 'uit de onderwijspraktijk' en voor de beste poster.

De jury bestond uit:

- Prof. dr. Anselme Derese (UGent), voorzitter

- Prof. dr. Peter Van Beukelen (UU, Diergeneeskunde)

- Dr. Johanna Schönrock-Adema (UMC Groningen)

- Marie-Claire Kleinegris (Studentenvertegenwoordiger in het bestuur van de NVMO en Universiteit Maastricht)

\section{Gevolgde procedure}

De jury voerde een eerste screening uit van de abstracts in het programmaboek. De geselecteerde bijdragen in de categorieën onderzoekspaper en paper 'uit de onderwijspraktijk' werden op het congres door minstens twee juryleden bijgewoond. De wetenschappelijke papers werden beoordeeld door één van de juryleden met onderzoekservaring en door de zaalvoorzitter. Alle posters die opgehangen werden in de foyer, werden nog eens door de juryleden bekeken. In elke categorie werden twee of meer bijdragen genomineerd. De keuze voor de beste bijdrage uit elke categorie gebeurde na intensieve deliberatie binnen de jury.

\section{Prijs voor elke categorie}

Elke prijswinnaar ontving op de slotzitting een bos bloemen en een boekenbon ter waarde van 150 euro, te kiezen uit het aanbod van BSL. De auteurs worden uitgenodigd hun bijdrage of ar- tikel te publiceren in het TMO en ontvangen één gratis deelname aan het NVMO-congres 2008. De abstracts van alle genomineerden worden in dit nummer van het Tijdschrift voor Medisch Onderwijs gepubliceerd.

\section{Nominaties}

Bij de nominaties en de uiteindelijke keuze van de beste bijdrage in elke categorie, werd rekening gehouden met de kwaliteit van de abstract, de kwaliteit van de poster, resp. de presentatie op het congres en de kenmerken originaliteit, toepasbaarheid van de conclusies in de reële onderwijspraktijk en het vernieuwende karakter.

\section{Genomineerden posters}

Marjo Wijnen-Meijer et al. (UMC Utrecht). De positie en terminologie van het schakeljaar: een internationale vergelijking.

In de poster wordt op basis van beschrijvingen van curricula van een aantal universiteiten een vergelijking gemaakt van de structuur en terminologie van de medische opleidingen in Nederland, Noord-Amerika, België en het Verenigd Koninkrijk. Het Nederlandse schakeljaar blijkt qua verantwoordelijkheden en bevoegdheden overeen te komen met het Noord-Amerikaanse internship, het Engelse pre-registration house-officer en het Belgische zevende jaar van de basisopleiding.

Marta Witkowska et al. (KU Leuven). Feedback: studenten willen meer!

De poster toont aan dat studenten zeer positief reageren op de feedback die ze van een wetenschappelijk medewerker kregen op een mondelinge presentatie die ze gaven op het 
einde van een vier weken durend geïntegreerd practicum in de 3de bachelor biomedische wetenschappen. De studenten kregen feedback op taalgebruik, intonatie, articulatie, volume, snelheid, enthousiasme, contact met het publiek, ruimtegebruik, houding en over de kwaliteit van hun Powerpoint presentatie. De studenten vonden de feedback nuttig en leerrijk. De helft pleitte ervoor om feedback als een vast onderdeel van het practicum te implementeren en zelfs uit te breiden naar vroegere jaren en andere opleidingsonderdelen.

De prijs voor de beste poster ging naar: Jessica van Nies et al. (LUMC). Is grootschalig onderwijs even effectief als kleinschalig onderwijs? Gerandomiseerd gecontroleerd onderzoek naar het verschil tussen de effectiviteit van grootschalig en kleinschalig onderwijs in een derdejaars blok geneeskunde.

De auteurs vonden geen verschil in effectiviteit tussen werkgroepen en werkcolleges in het blok en concluderen dat het goed is om de studenten keuzevrijheid te geven en ze ook in de toekomst naast werkgroep als alternatief werkcollege aan te bieden.

Als algemene opmerking bij deze categorie vond de jury dat de posters in het algemeen op vlak van visuele attractiviteit verbeterd kunnen worden.

\section{Genomineerden onderzoekspapers}

Meta Schoonheim-Klein et al. (ACTA/Universiteit Maastricht). Vergelijking van twee normeringsmethoden voor een tandheelkundige OSCE met behulp van gewogen verlies en betrouwbaarheid.

De auteurs vergeleken de Borderline Regressie methode met de Angoff methode voor het bepalen van de slaag/zakgrens of cesuur. $\mathrm{Zij}$ concluderen dat de Borderline Regressie methode een meer geloofwaardige en meer betrouwbare uitslag geeft dan de Angoff methode en daarom de beste methode blijkt voor deze tandheelkundige OSCE.

De prijs voor de beste onderzoekspaper ging naar:

Martine Boerjan et al. (UMC St Radboud/UGent). Simulatiepatiënten en herhaalde simulatie van medische condities, wat zijn de gevolgen?

De auteur is een studente uit Nijmegen die het onderzoek deed in het kader van haar onderzoeksstage aan de Universiteit Gent. Zij voerde bij acht ervaren simulatiepatiënten semi-gestructureerde interviews uit, waaruit bleek dat simuleren van medische condities zowel positieve als negatieve effecten heeft. Simuleren geeft plezier en tevredenheid en werkt voor sommigen zelfs therapeutisch, maar het kan ook gevoel van verhoogde kwetsbaarheid, stress en angst veroorzaken voorafgaand aan volgende simulaties. De jury waardeert het dat in dit onderzoek aandacht wordt besteed aan een relatief vergeten effect van het inzetten van simulatiepatiënten in het praktische medische onderwijs.

\section{Genomineerden papers 'uit de onderwijs- praktijk':}

Paul Gobée et al. (LUMC). Vernieuwing van microscopieonderwijs door middel van Blended Learning.

De auteur beschrijft een onderwijsinnovatie waarbij een hands-on practicum in de microscopiezaal wordt voorafgegaan door een computerles op Blackboard. Een toets op het einde van het doorlopen van de computerles verplicht de studenten om daar voldoende aandacht aan te besteden. De computerles maakt gebruik van virtuele microscopie. In de handson sessie wordt verdieping geboden.

Luuk van Lonkhuijzen et al. Naar kwaliteitssystemen in de medische vervolgopleidingen.

De auteurs beschrijven hoe het binnen een Onderwijs- en OpleidingsRegio (OOR) moge- 
lijk bleek de kwaliteit van de opleiding en het opleidingsklimaat per kliniek te verbeteren. De gezonde concurrentie tussen de klinieken bleek daarbij een duidelijke stimulans. Voor de evaluatie van de kwaliteit werd gebruikt gemaakt van gevalideerde vragenlijsten: de Postgraduate Hospital Education Environment Measure (PHEEM) en het Clinical Teaching Effectiveness Instrument (CTEI).

Wieger van der Meulen et al. (UMcG). De selectiemethodiek van opleiders bij de huisartsopleiding ter discussie.

De auteurs kijken kritisch naar de selectieprocedure van huisartsenopleiders in Groningen. De huidige selectieprocedure kan op diverse punten worden verbeterd. De selectiecriteria kunnen zowel voor de kandidaten als voor de toetsende stafleden duidelijker worden gemaakt. Het gebruik van nieuwe selectie-instrumenten wordt aanbevolen, evenals een proeftijd als opleider.

De prijs voor de beste paper uit de onderwijspraktijk ging uiteindelijk naar de bijdrage van het $K N M G$-studentenplatform, in de persoon van Maarten Anderegg. Burn-out bij coassistenten.

Uit het onderzoek blijkt dat één derde van de coassistenten regelmatig last heeft van burnout. Angst voor persoonlijk falen en de hoge werkdruk lijken hierin een belangrijke rol te spelen. Zij geven aan dat emotionele ondersteuning vanwege de faculteit tekort schiet. Faculteiten en opleiders zouden hieraan meer aandacht moeten besteden.

\section{Genomineerden wetenschappelijke papers}

De jury was in deze categorie erg onder de indruk van de kwaliteit van de bijdragen. Het was dan ook bijzonder moeilijk om uit de genomineerden één beste bijdrage te selecteren. De volgende bijdragen haalden het net niet:

Klarke Boor et al. (VUmc). Hoe klinische opleidingsklimaten verschillen: een gecombineerde kwantitatieve en kwalitatieve studie.
Deze studie maakt eveneens gebruik van de PHEEM, met als doel de opleidingsklimaten te vergelijken in verschillende stageplaatsen voor coassistenten. De bevindingen kunnen vergeleken worden met die uit een Britse studie waarin twee benaderingen van participatie worden herkend: een 'expanded approach' en een 'restrictive approach'.

Hanke Dekker et al. (UMCG/RUG). Kenmerken van reflectiestimulerende schriftelijke feedback in portfolio's.

Geconcludeerd kan worden dat bij portfolio's schriftelijke feedback te karakteriseren is op drie dimensies. Feedback in vraagvorm en gericht op persoonlijke ontwikkeling lijkt reflectie het meest te stimuleren. Docenten dienen uitvoerig te worden getraind in het geven van reflectiestimulerende schriftelijke portfoliofeedback.

Marjolein Heijne-Penninga et al. (UMCG/ RUG). De invloed van diepgaand leren en intellectualiteit op de resultaten van open en gesloten boek-toetsen.

De auteurs vergelijken open en geslotenboek toetsen en vinden voor geen van beide toetsvormen een verband tussen diepgaand leren en resultaat. $\mathrm{Zij}$ stellen de vraag of diepgaand leren nog steeds het meest wenselijk is in de huidige tijd, met de huidige generatie studenten.

Uiteindelijk werd de bijdrage geselecteerd van Ally van Hell et al.(UMCG). Tijdsbesteding van coassistenten en perceptie van de leeromgeving. Uit het onderzoek blijkt dat een deel van de coassistenten méér dan acht uur per dag werkt. De tijdsbesteding aan onderwijs, begeleiding en het zelfstandig uitvoeren van consulten blijkt niet samen te hangen met een hogere gepercipieerde kwaliteit van de leeromgeving. De auteur besluit dat nog onderzocht moet worden wat het relatieve belang is van de duur van de werkzaamheden voor de gepercipieerde leerzaamheid van het coassistentschap. 
In het algemeen was de jury erg positief over het gebruik van literatuurverwijzingen ter verantwoording van beweringen op de Powerpoint presentaties van de genomineerde kandidaten.

\section{Anselm Derese}

Voorzitter jury NVMO-congres 2007

\section{Posters}

\section{Is grootschalig onderwijs even effectief} als kleinschalig onderwijs? Gerandomiseerd gecontroleerd onderzoek naar het verschil tussen de effectiviteit van grootschalig en kleinschalig onderwijs in een derdejaars blok Geneeskunde

\section{J.A.B. van Nies, S.W.M. Peters, S.Dijkstra, D.D. Mansvelder-Longayroux, F.W. Dekker, Z. de Jong}

Probleemstelling: Uit ons in 2006 gepresenteerd onderzoek is gebleken dat, indien de keuze geboden wordt, ruim een derde deel van de studenten werkcolleges (grootschalige setting, zonder inschrijving vooraf, dezelfde stof in hetzelfde tijdsbestek als in werkgroep) prefereert boven werkgroepen (15 studenten/docent, inschrijving vooraf verplicht). We konden echter niet tot een sluitende conclusie komen wat betreft de effectiviteit. Dit abstract rapporteert de resultaten van een gerandomiseerd onderzoek (RCT) dat wederom plaats vond in blok Bewegingsapparaat (BA). Deze trial vergelijkt de effectiviteit van werkgroepen versus werkcolleges en de tevredenheid van deelnemers met het ontvangen werkonderwijs.

Methode: Alle potentiële deelnemers aan het blok BA (driewekelijks blok met drie werkgroepen/of werkcolleges in totaal) werden gevraagd om deel te nemen aan het onderzoek. De deelnemers werden gerandomiseerd tussen werkgroepen (WG) en werkcolleges (WC). De nietdeelnemers hadden een vrije keuze.

Als maat voor de effectiviteit van de werkwijze werd de uitslag van het tentamen ge- bruikt. Naast meerkeuzevragen (MC) en extending-matching (EM) vragen waren er ook twee open vragen waarin de in WG en WC geoefende denkwijze moest worden toegepast. De tevredenheid werd onderzocht door middel van een schriftelijke enquête die na het tentamen werd gehouden. De verschillen tussen de groepen werden geanalyseerd met chi-kwadraat en Ttoets als geïndiceerd.

Resultaten: 107 (53 WG en 54 WC) RCT deelnemers hebben de beoogde interventie gevolgd en gegevens aangeleverd. In totaal 99 studenten hebben niet deelgenomen aan het onderzoek (51 WG, 38 WC en 10 geen van de beide interventies). Voor de huidige analyse werden alleen de gegevens van de RCT deelnemers gebruikt.

Er was geen significant verschil tussen de WG en WC deelnemers in het gemiddelde eindcijfer (SD) behaald voor het bloktentamen BA (6.6 (1.1) resp. 6.6 (1.0)) noch voor de gemiddelde score voor MC vragen, EM vragen en open vragen.

Het merendeel van de WG deelnemers $(86,7 \%)$ was tevreden met de werkgroepdocenten en $86,7 \%$ was achteraf tevreden gerandomiseerd te zijn in WG.

Het merendeel van de WC deelnemers (85\%) was ook tevreden met de docenten en 37,5\% was tevreden gerandomiseerd te zijn in de WC. Van de WC deelnemers vond 50\% dat tijdens de werkcolleges actiever door de studenten werd meegedaan dan dat ze van hoorcolleges gewend zijn; 43,5\% WG versus 45\% WC deelnemers voelde zich goed voorbereid voor het tentamen. Conclusie: Er is geen verschil in de effectiviteit van de werkgroepen en werkcolleges in dit blok. Zowel de deelnemers aan WG als WC waren merendeels tevreden met de kwaliteit van het geboden werkonderwijs en voelden zich goed voorbereid voor het tentamen. Wij concluderen dat het goed is om de studenten keuzevrijheid te geven en ze ook in de toekomst naast werkgroep als alternatief werkcollege aan te bieden.

Correspondentieadres:

Dr. Z. de Jong, LUMC, Reumatologie, Keizersgracht 255, 1016 EB Amsterdam. 


\section{De positie en terminologie van het schakeljaar: een internationale vergelijking}

\section{Wijnen-Meijer, Th.J. ten Cate, J.C.C. Borleffs}

Probleemstelling: Aan een aantal Nederlandse universiteiten is recent het zogenaamde schakeljaar ingevoerd, met als doel de doorstroming van de basis- naar de vervolgopleiding te versoepelen. Gedurende dit schakeljaar kiest de student een aantal (langere) stages, waardoor de student eerder in het traject moet nadenken over de gewenste richting van de vervolgopleiding. Tijdens deze stages werkt de student als semi-arts zelfstandiger en met meer verantwoordelijkheid dan tijdens de coschappen. Bij internationale vergelijkingen blijkt dat de positionering van het schakeljaar tot spraakverwarring kan leiden. Is een coassistent, semi-arts, anios en aios nu het best te vergelijken met een clerk, een intern, een house-officer, een resident of een registrar? Daarnaast zijn de bevoegdheden en het moment van beperkte en volledige opname in een register niet uniform in internationaal perspectief. Hoe moet het schakeljaar in internationaal perspectief gepositioneerd worden? Het doel van deze bijdrage is een helder overzicht te geven in dit veld.

Methode: Op basis van beschrijvingen van curricula van een aantal universiteiten, is een vergelijking gemaakt van de structuur en terminologie van de medische opleidingen in Nederland, Noord-Amerika, België, het Verenigd Koninkrijk (oude en nieuwe systeem) en Zweden. Bij deze vergelijking zijn de volgende parameters gebruikt: mate van verantwoordelijkheid, duur van de stages, keuzemogelijkheden, bevoegdheden en registratiestatus.

Resultaten en conclusie: Wat betreft de positie van het schakeljaar is de conclusie dat dit jaar in chronologisch opzicht het laatste jaar van de basisopleiding is. Qua verantwoordelijkheden en bevoegdheden zijn er meer overeenkomsten met het Noord-Amerikaanse internship, het Engelse pre-registration house-officer of het eerste jaar van het nieuwe foundation programme en het Belgische zevende jaar. In Zweden is er geen keuze wat betreft de invulling van de stages.

Deze vergelijking beperkt zich tot vijf modellen die regelmatig in de literatuur genoemd worden. Er bestaan meer modellen. In een volgende rapportage zal hier aandacht aan besteed worden.

Correspondentieadres:

Drs. M. Wijnen-Meijer, UMC Utrecht, Expertisecentrum voor Onderwijs \& Opl., Huispost HB 4.05, Postbus 85500, 3508 GA Utrecht.

\section{Feedback: studenten willen meer!}

\section{Witkowska, N. Druine, A. Desmet}

Probleemstelling: Uit de literatuur blijkt dat feedback zeer leerzaam kan zijn voor studenten. De beste feedback komt zo kort mogelijk na de prestatie, is geïndividualiseerd en bevat tips voor de toekomst. Feedback is vooral wenselijk bij vaardigheden, die bijgestuurd kunnen worden vanuit deze feedback (in dit geval presentatievaardigheden). De studenten aan de Faculteit Geneeskunde krijgen meestal enkel de punten en zelden commentaar op hun prestatie. We boden hen feedback aan over hun mondelinge presentatie. Geïndividualiseerde feedback is tijdsintensief en vraagt bijgevolg een grondige afweging van kosten en baten. We wilden een antwoord krijgen op de volgende vragen: Wat vinden de studenten van de feedback? Hebben ze er iets uit geleerd?

Opzet: Op het einde van het vier weken durende geïntegreerde practicum in het derde jaar bachelor Biomedische Wetenschappen geven de studenten een mondelinge presentatie. De wetenschappelijk medewerker volgde alle presentaties en gaf elke student kort erna persoonlijk schriftelijke feedback met tips ter verbetering. De volgende aspecten werden beoordeeld: taalgebruik, intonatie, articulatie, vo- 
lume, snelheid, enthousiasme, contact met het publiek, ruimtegebruik, houding en kwaliteit van de Powerpointpresentatie.

Methode: Na afloop van het practicum kregen alle studenten $(\mathrm{n}=87)$ een e-mail. Hierin werden ze uitgenodigd om aan de hand van enkele open vragen hun mening te geven over de gekregen feedback. De e-mail kwam van de wetenschappelijk medewerker en niet van de docenten, waardoor we hoopten sociaal wenselijke reacties tot een minimum te beperken. Na twee weken ontvingen de studenten een herinneringsmail.

Resultaten: De respons was 46\% ( $n=40)$. Het moment van de oproep was niet ideaal, aangezien dit tijdens de examenperiode viel. Alle 40 studenten zijn zeer enthousiast over deze feedback, ze vinden het nuttig en leerrijk. $75 \%$ van de respondenten gaf expliciet aan de tips zeker te gebruiken. De helft pleitte ervoor om feedback als een vast onderdeel van het practicum te implementeren en zelfs uit te breiden naar vroegere jaren en andere opleidingsonderdelen. Conclusie: De reacties van de studenten over de gekregen feedback waren zeer positief. Ze bevestigen de in de literatuur aangehaalde voordelen van feedback. De vrij lage respons heeft mogelijk een positieve bias op de resultaten. Misschien zijn het vooral enthousiaste studenten die gereageerd hebben? Uit ervaring met studentenbevragingen weten we echter dat het meestal de meest ontevreden studenten zijn die hun stem laten horen.

Deze gegevens zijn ook voor de facultaire beleidsverantwoordelijken een stimulans om het geven van feedback verder te implementeren. Uiteraard is het ook van belang na te gaan of feedback de prestatie van de student gunstig beïnvloedt. We willen dit in de toekomst verder onderzoeken.

Correspondentieadres:

M. Witkowska, Katholieke Universiteit Leuven, Dienst Onderwijs Geneeskunde, Campus Gasthuisberg, Herestraat 49, O\&N2, bus 400, 3000 Leuven, België. E-mail: marta.witkowska@med.kuleuven.be

\section{Onderzoekspapers}

\section{Simulatiepatiënten en herhaalde simula- tie van medische condities, wat zijn de ge- volgen?}

\section{Boerjan, F. Boone, S. Anthierens, E.M. van Weel-Baumgarten, M. Deveugele}

Probleemstelling: Simulatiepatiënten worden al sinds eind jaren '60 ingezet in (medisch) onderwijs om klinische en communicatieve vaardigheden van studenten te trainen en te evalueren. Eerder onderzoek heeft zich vooral gericht op de simulatiepatiënt als 'didactisch instrument' waarbij toepasbaarheid, betrouwbaarheid en validiteit centraal staan. Desondanks is dit 'didactisch instrument' een individu en is het niet onwaarschijnlijk dat simuleren persoonlijke gevolgen heeft. Dit onderzoek richt zich op de invloed van simuleren op het welzijn, de perceptie van de eigen gezondheid en de relatie met de eigen arts.

Methode/opzet: In een kwalitatief onderzoek zijn bij acht ervaren simulatiepatiënten semigestructureerde interviews afgenomen. Deze interviews zijn geanalyseerd met behulp van de 'modified grounded theory analysis approach', waarbij vanuit de interviews thema's zijn ontwikkeld door middel van open en axiaal coderen.

Resultaten: Invloed op welbevinden. Simuleren van medische condities geeft positieve en negatieve effecten. Positief zijn: plezier en tevredenheid. Voor sommigen werkt simuleren zelfs therapeutisch. Negatief zijn: een gevoel van verhoogde kwetsbaarheid, stress en angst voorafgaand aan simulaties. Verder veroorzaken zowel de rol, overeenkomsten van die rol met hun eigen leven en het gedrag van studenten emoties. Deze emoties leiden tot moeheid, ontevredenheid over de eigen prestatie en slaapproblemen na het simuleren.

Invloed op de perceptie van de eigen gezondheid. Simulatiepatiënten ervaren hun medische kennis als toegenomen. Dit leidt tot een andere manier van omgaan met eigen sympto- 
men: ze onderscheiden ernstige beter van minder ernstige symptomen, zoeken meer medische informatie op en gebruiken adviezen die ze hebben gekregen tijdens het rollenspel, voor zichzelf. Zij hebben het idee dat ze door deze drie veranderingen de huisarts minder vaak consulteren dan voorheen.

Invloed op de relatie met de eigen arts. Het werk als simulatiepatiënt geeft meer inzicht in de vaardigheden die een arts dient te hebben en in de complexiteit van het artsenberoep. Daarbij realiseren simulatiepatiënten zich dat voor dezelfde symptomen verschillende artsen verschillende therapieën geven. Hierdoor gaan zij hun arts minder als autoriteit zien en worden zij tijdens consulten met hun arts kritischer, assertiever en alerter dan voorheen.

Discussie/implicaties voor de praktijk: Stress voorafgaand aan het simuleren is wellicht geen negatief effect, omdat deze juist positief kan bijdragen aan het spelen van een rol. Daarentegen zijn de effecten na het simuleren (moeheid, ontevredenheid en slaapproblemen) ongewenst. De ervaren toename in medische kennis leidt tot een andere manier van omgaan met eigen symptomen. Dit is zorgwekkend, omdat de verkregen informatie tijdens het rollenspel vaak incompleet en soms zelfs onjuist kan zijn. Ten slotte geeft het werk als simulatiepatiënt handreikingen om voor het eigen gevoel beter te communiceren met de arts.

Met behulp van goede selectie, voorbereiding en debriefing kunnen de negatieve effecten mogelijkerwijs verminderd worden.

Correspondentieadres:

M. Boerjan, UMC St Radboud, Huisartsgeneeskunde 117, p/a Weverstraat 29, 5612 CW Eindhoven. Email: m.boerjan@student.ru.nl

\section{Vergelijking van twee normeringmetho- den voor een tandheelkundige OSCE met behulp van gewogen verlies en betrouw- baarheid}

M.E. Schoonheim-Klein, L.L.M.H. Habets, A. Muijtjens, U. van der Velden, C.P.M. van der Vleuten

Inleiding: Onterecht gezakte studenten voor klinische eindexamens kunnen door herkansing alsnog slagen, maar de beslissing onvoldoende competente studenten te laten slagen is nooit terug te draaien en heeft consequenties voor de kwaliteit van de zorg. Beslissingen over slagen en zakken worden genomen op grond van cesuurbepalingen door toepassing van een normeringmethode. Vanwege inconsistente resultaten van studies naar betrouwbaarheid en geloofwaardigheid van normeringmethodes voor OSCEs, is het doel van deze studie de geloofwaardigheid en betrouwbaarheid te onderzoeken van de Angoff en de Borderline Regressie (BR) normeringmethode voor een tandheelkundige OSCE.

Materiaal en methode: In hun eerste jaar in de onderwijspraktijk kregen studenten tandheelkunde $1 \mathrm{x}$ per week feedback (elektronisch vastgelegd) van hun begeleider. Aan het eind van dit jaar, voor de overgang naar de Masterfase, kregen studenten een globale overallpraktijkbeoordeling van hun begeleider op een vijf-puntsschaal: $84 \%$ werd voldoende competent beoordeeld.

Daarnaast werden studenten $(\mathrm{n}=119)$ beoordeeld d.m.v. een OSCE met 14 stations uit vier competentiedomeinen/inhoudsgebieden. In 5-minuten stations werd de student beoordeeld met een criteriumlijst, resulterend in een checklistscore (1-10) en onafhankelijk daarvan kreeg de student bij het betreffende station een globale beoordeling (1-5). De BR-cesuur per OSCE-station werd bepaald door de checklistscores met lineaire regressie te vergelijken met de globale scores. Een inhoudsdeskundige jury bepaalde een Angoff-cesuur voor elk station. 
Het slagen voor de hele OSCE werd berekend met compensatie van stations binnen de vier competentiedomeinen. Alle domeinen moesten voldoende zijn.

Betrouwbaarheid van beide normeringmethoden werd bepaald met RMSE, de error van de cesuur, uitgedrukt op de scoreschaal. Daarnaast werden de BR-methode en de Angoff-methode op criteriumvaliditeit (geloofwaardigheid) vergeleken met het praktijkoordeel. Het slagen van een onvoldoende student werd een ernstiger fout geacht dan het zakken van een competente student en werd daarom een groter gewicht (verlies) toegekend, variërend van 1 tot 10 . Om vast te stellen welke normeringmethode minimaal verlies door foute kwalificaties oplevert (het meest geloofwaardig), werd het gewogen verlies geanalyseerd van beide normeringmethoden. Het gewogen verlies werd gedefinieerd als een gewogen som van sensitiviteit (terecht geslaagden/competenten) en specificiteit (terecht gezakten/incompetenten).

Resultaten: Slagingspercentages van Angoffen BR-methode waren $34,5 \%$ en $61,3 \%$.

Voor het gewicht variërend van 1-10 was het verlies van de BR-methode $(0,34-0,74)$ in alle gevallen kleiner dan dat van de Angoff-methode $(0,58-0,79)$.

De betrouwbaarheid (RMSE) van de cesuur per competentiedomein was voor de Angoff-cesuur 1,8\%-2,2\% en voor de BR-cesuur 0,6\%-0,7\%. Conclusie: Bij het hanteren van compensatie binnen competentiedomeinen geeft de Borderline Regressiemethode een meer geloofwaardige en meer betrouwbare uitslag dan de Angoff-methode en lijkt daarom de beste methode voor deze tandheelkundige OSCE.

\section{Correspondentieadres:}

M.E. Schoonheim-Klein, ACTA, Parodontologie, Louwesweg 1, 1066 EA Amsterdam.

Email:m.schoonheim@acta.nl

\section{Papers uit de Onderwijspraktijk}

\section{Burn-out bij coassistenten}

\section{KNMG-studentenplatform}

Probleemstelling: In december 2006 werd in Medisch Contact bericht over een hoge prevalentie van burn-outverschijnselen onder artsassistenten in Nederland. Ook coassistenten vormen een groep die vanwege lange werktijden, steeds veranderende werkomgeving of moeite met het maken van loopbaankeuzes wellicht vatbaar is voor burn-out gerelateerde verschijnselen. Stress tijdens de coschappen wordt zelfs genoemd als predictor voor burnout tijdens de assistentschappen.

Doel: Het KNMG Studentenplatform wil onderzoeken of onder coassistenten burn-out gerelateerde verschijnselen vóórkomen en wat daarvan de oorzaken zijn. Daarnaast wil het KNMG Studentenplatform inventariseren of coassistenten vinden dat facultaire vertrouwenspersonen hierover benaderbaar zijn en hulp kunnen bieden.

Methode: Jaarlijks houdt het KNMG Studentenplatform een Studentenpanel (digitale enquête) onder alle studentleden van de KNMG. Geneeskunde studenten van alle studiejaren en faculteiten worden hiervoor benaderd. Aan alle coassistenten in het Studentenpanel van 2007 is gevraagd of zij op regelmatige basis hun coschappen niet meer zien zitten en in hoeverre zij dit als gevolg zien van een te hoge werkdruk, emotionele overbelasting, privéomstandigheden of angst voor persoonlijk falen. Aanvullend werd hen gevraagd hoeveel uren per week zij in het ziekenhuis werkzaam zijn en hoe zij de kwaliteit en bereikbaarheid van de emotionele ondersteuning en begeleiding binnen de faculteit beoordelen.

Daarnaast zijn de studieadviseurs van de acht geneeskunde faculteiten in Nederland benaderd. Hen zijn vragen voorgelegd over de ervaring met burn-outverschijnselen onder coassis- 
tenten. Ook is gevraagd naar hun mening over de eigen toegankelijkheid en bereikbaarheid.

Resultaten: Van de 6.216 benaderde studenten hebben 1.982 gerespondeerd (responspercentage 31,9\%). De respondenten zijn representatief voor de populatie geneeskunde studenten in Nederland voor wat betreft geslacht, faculteit en studiejaar.

Van de groep respondenten gaf $40 \%$ aan met de coschappen begonnen te zijn. Ruim een derde van hen (35\%) geeft aan de coschappen regelmatig niet meer te zien zitten op basis van angst voor persoonlijk falen. In 33\% van de gevallen ziet een coassistent het niet meer zitten vanwege een hoge werkdruk. Privéomstandigheden (15\%) en emotioneel zwaar werk (14\%) zijn minder vaak een oorzaak.

Coassistenten die $>50$ uur per week werken (41\% van de coassistenten), geven vaker aan dan coassistenten die $<40$ uur per week werken dat ze het niet meer zien zitten door hoge werkdruk (43\% vs. $26 \%$ ) en emotioneel zwaar werk (18\% vs. $9 \%)$.

Slechts $51 \%$ van de coassistenten is van mening dat de, voor deze problematiek aangewezen instanties binnen de faculteit (opleiders, docenten, vertrouwenspersonen) voldoende bereikbaar zijn. Ruim 38\% beoordeelt de emotionele ondersteuning vanuit deze instanties als onvoldoende.

In deze laatste resultaten schuilt tegenstrijdigheid met de antwoorden van de studieadviseurs; deze waren over het algemeen van mening goed bereikbaar te zijn voor de geneeskunde studenten.

Conclusie: Uit ons onderzoek blijkt dat ruim een derde van de coassistenten aangeeft dat zij de coschappen regelmatig niet meer zien zitten. Ondermeer angst voor persoonlijk falen en een hoge werkdruk spelen hierbij een belangrijke rol. Hoewel bij deze responsgraad de representativiteit van deze resultaten goed in ogenschouw genomen moet worden, ziet het KNMG Studentenplatform een trend in het vóórkomen van burn-out gerelateerde verschijnselen onder coassistenten. De meerder- heid van de coassistenten geeft bovendien aan dat de emotionele ondersteuning binnen de faculteit tekort schiet. Faculteiten en opleiders zouden hieraan meer aandacht moeten besteden en zouden hiervoor beter bereikbaar moeten zijn.

Correspondentieadres:

KNMG Studentenplatform, p/a Janvossensteeg 7A, 2312 WB Leiden. Email: ronvanoosterhout@hotmail.com

\section{Vernieuwing van microscopie onderwijs door middel van 'Blended Learning'}

\section{O.P. Gobée}

Probleemstelling: Het histologieonderwijs vindt vanouds plaats in practica, waarbij studenten aan een tweekops-microscoop preparaten bekijken en de waargenomen structuren tekenen. Er rees behoefte aan vernieuwing vanwege verschillende argumenten:

- niet elk exemplaar van het preparaat toont de gezochte structuren even goed,

- studenten hebben weerzin tegen het tekenen,

- de ruime inzet van assistenten bij deze practica is kostbaar.

Aangezien de afdeling zelf computeronderwijs ontwikkelt, werd gedacht dit in te zetten. Gezocht werd naar een geschikt format, waarbij de studieresultaten liefst zouden verbeteren of tenminste gelijk blijven.

Methode/opzet: Gekozen werd voor een 'blended learning' opzet. Onder 'blended learning' wordt verstaan: een combinatie van e-learning en contactonderwijs. De studenten krijgen eerst een online computerles en vervolgens een 'hands-on' microscopiesessie. In de computerles worden de basisbegrippen behandeld en wordt ingegaan op de relatie tussen weefselvorm en -functie. Naast theorie bevat de computerles een geïntegreerde virtuele microscoop (http://www.path.uiowa.edu/ virtualslidebox/), waarbij vragen gesteld worden. In de hands-on sessie wordt vervolgens verdieping geboden. 
Resultaten: De resultaten vielen oorspronkelijk tegen. We namen waar dat de studenten soms zonder nadenken 'door de computerles heen klikten' en dat de stof blijkbaar niet duidelijk genoeg overkwam; men stelde erg basale vragen. Bij het opvolgende hands-on practicum bleek men minder te weten dan in voorgaande jaren en de toets bleek slechter gemaakt. We overwogen de volgende oorzaken:

- de lesvorm daagde onvoldoende uit en er was onvoldoende 'stok achter de deur'. Alleen aantrekkelijk aanbieden bleek toch niet genoeg bij een onderwerp dat veel medisch studenten minder aanspreekt,

- er was onvoldoende 'beeld-feedback'. Als je niet wist hoe een structuur eruitzag, wist je het na de les nog niet.

Daarop werden de volgende aanpassingen doorgevoerd:

- tussen de computerles en het hands-on practicum werd een Blackboard toets geplaatst, welke men voldoende dient te hebben voor toelating tot het practicum,

- om ongericht klikken te ontmoedigen, werd een scoringssysteem ingebouwd, waarbij men meer punten krijgt als men een vraag de eerste keer juist beantwoordt. Bij voldoende punten kan men als beloning een samenvatting downloaden,

- alle vragen werden voorzien van uitgebreide tekstuele en visuele feedback.

In de aangepaste opzet hadden we de indruk dat de studenten inhoudelijk goed en intensief de computerles bestudeerden. We vonden de door studenten gestelde vragen een goede diepgang hebben en het kennisniveau bij het handson practicum sterk verbeterd. Ook de toetsresultaten waren weer gestegen.

\section{Conclusie/aanbevelingen:}

- een 'blended learning' opzet werkt goed,

- naast een intrinsiek motiverende les blijft een extrinsieke motivatie (toets) onontbeerlijk,

- de optimale opzet en interface van computeronderwijs wordt bereikt door bijstelling aan de hand van ervaringen.
Correspondentieadres:

O.P. Gobée, LUMC, Anatomie en Embryologie, Postbus 9600, Postzone S-1-P, 2300 RC Leiden. Email: o.p.gobee@lumc.nl

\section{Naar kwaliteitssystemen in de medische vervolgopleidingen}

\section{L.R.C.W. van Lonkhuijzen, M.J.E. Mourits, H.P. Eising, P. Remmelts, E. Jippes}

Probleemstelling: De medische vervolgopleidingen worden momenteel ingrijpend gewijzigd. De belangrijkste verandering bestaat uit de invoering van het competentiegerichte leren. Om competenties te ontwikkelen dient de aios expliciete en gestructureerde feedback te krijgen. Echter ook de opleiding zelf dient onderwerp te zijn van reflectie en feedback om deze te verbeteren. Uiteraard is er de verplichte vijfjaarlijkse opleidingsvisitatie, maar deze garandeert niet dat de kwaliteit voortdurend op de agenda staat. De opleiding Obstetrie \& Gynaecologie in de Onderwijs en OpleidingsRegio (OOR) Noord- en Oost Nederland heeft in de vorm van een jaarlijkse regionale evaluatiedag aan deze vorm van kwaliteitszorg een invulling gegeven. Hoe heeft deze dag zich in de loop der tijd ontwikkeld en hoe haalt een opleiding het maximale rendement hieruit?

Methode/opzet: De regie voor de jaarlijkse evaluatie is in handen van de aios op de universitaire locatie. Aanwezig zijn alle opleiders, plaatsvervangend opleiders en aios uit de verschillende opleidingsklinieken van de OOR. Bij eerdere bijeenkomsten lag de nadruk meer op kwantitatieve (productie)gegevens, de laatste jaren worden ook meer kwalitatieve gegevens (zoals opleidingsklimaat, geboden supervisie, veiligheid) besproken. Deze gegevens worden verzameld door de aios in iedere afzonderlijke kliniek en plenair per kliniek gepresenteerd en bediscussieerd. Vervolgens worden afspraken gemaakt voor verbeteringen het komende jaar. Vanuit de behoefte om de kwaliteitszorg voor de opleiding verder te professionaliseren zijn 
het afgelopen jaar enkele gevalideerde vragenlijsten geïntroduceerd:

- op systeemniveau: de Posgraduate Hospital Education Environment Measure (PHEEM) waarmee het leerklimaat van iedere kliniek in kaart wordt gebracht. De resultaten hiervan worden besproken op de evaluatiedag,

- op systeem- en individueel niveau: de Clinical Teaching Effectiveness Instrument (CTEI) waarmee de individuele docentcompetenties van de supervisoren en de geaggregeerde teamcompetenties in beeld worden gebracht. Teamscores worden besproken tijdens de evaluatiedag, terwijl de individuele scores worden besproken tussen aios en ieder staflid afzonderlijk.

Resultaten/evaluatie: Het jaarlijks evalueren van de opleiding door aios aan de hand van productiegegevens biedt aanknopingspunten voor verbetering. De meer kwalitatieve resultaten van de PHEEM en de CTEI vullen deze resultaten per kliniek aan (op het gebied van leerklimaat en docentcompetenties) en maken objectieve vergelijkingen tussen klinieken en opleiders mogelijk. Heldere afspraken dienen te worden gemaakt over doel, vertrouwelijkheid van de gegevens, wijze en consequenties van terugkoppeling.

Conclusie/implicaties voor de praktijk: Het binnen een OOR openlijk bespreken van de kwaliteit van de opleiding en het opleidingsklimaat per kliniek is mogelijk. Aios en supervisoren ervaren de evaluatie als stimulerend en waardevol en voelen zich betrokken bij de opleiding(svernieuwingen). De gezonde concurrentie tussen de klinieken binnen een OOR blijkt een duidelijke stimulans voor verbetering. De introductie van de PHEEM en zeker de CTEI dragen bij tot een objectivering van de evaluatie en maken vergelijkingen tussen klinieken en opleiders longitudinaal mogelijk.

Correspondentieadres:

Drs. E Jippes, UMCG, Wenckebach Instituut, Hanzeplein 1, 9700 RB Groningen.

\section{De selectiemethodiek van opleiders bij de huisartsopleiding ter discussie}

\section{W.K. van der Meulen WK, P.M. Boendermaker}

Inleiding: Tijdens de selectieprocedure voor huisartsopleiders, die willen gaan opleiden voor de huisartsopleiding Groningen, wordt geprobeerd om de competenties die verwacht worden van kandidaat-huisartsopleiders zo goed mogelijk in kaart te brengen. Deze selectieprocedure, en de subjectieve interpretatie ervan, staat ter discussie. De huidige procedure is niet gestructureerd, is sterk afhankelijk van de personen die de selectieprocedure uitvoeren en is zeer informeel van opzet. Door het ontbreken van heldere indicatoren is het onderling vergelijken van kandidaten moeilijk en daaraan gekoppeld het toelaten/afwijzen van een kandidaat-huisartsopleider voor het opleiderschap. Om deze problemen in de toekomst te vermijden heeft de huisartsopleiding Groningen besloten om kritisch te kijken naar de selectieprocedure van huisartsopleiders. Dit leidt tot de vraag: welke selectie-instrumenten heeft de huisartsopleiding Groningen nodig om te bepalen of een kandidaat-huisartsopleider beschikt over de gewenste competenties?

Vraagstelling: Om de vraag te kunnen beantwoorden, zijn de volgende deelvragen beantwoord:

- Over welke competenties moet een startende huisartsopleider beschikken?

- In hoeverre is de huidige procedure toereikend om de vereiste competenties in beeld te krijgen?

- Welke selectie-instrumenten kunnen worden gebruikt om het huidige selectieproces te verbeteren?

Methode: Er zijn twee methoden ingezet om de vragen te beantwoorden. Informatie is verkregen door mondelinge interviews met de vier meest betrokken stafleden en deze gegevens zijn aangevuld met bestaande schriftelijke informatie uit diverse bronnen. $\mathrm{Al}$ deze gegevens 
zijn afgezet tegen de in Human Resource Management aanwezige kennis over dergelijke selectieprocedures.

Uitkomsten: De schriftelijke informatie leverde een beeld op van een zorgvuldig gedocumenteerde competentiebeschrijving voor de huisartsopleider, die lastig naar de praktijk te vertalen blijkt te zijn. Door de interviews is de huidige selectieprocedure in kaart gebracht en is vastgesteld welke competenties in het bijzonder belangrijk worden geacht vanuit de huisartsopleiding Groningen. De huidige selectiemethoden, waaronder een introductiecursus van twee dagen die ook de vorm van een assessment heeft, bleken op diverse punten, zoals validiteit en betrouwbaarheid, niet te voldoen.

Conclusies en beschouwing: De huidige selectieprocedure kan op diverse punten worden verbeterd. De selectiecriteria kunnen zowel voor de kandidaten als voor de toetsende stafleden duidelijker worden gemaakt. Bovendien kunnen de instructies voor de stafleden worden verbeterd. Naast aanscherping van de bestaande methoden, kan de procedure worden uitgebreid met nieuwe selectie-instrumenten. Tenslotte is een proeftijd als opleider ook een reële optie. Er is een advies uitgebracht ter verbetering van de reeds gebruikte technieken en methoden en ten aanzien van aanvullende instrumenten. Het advies wordt ondersteund door een implementatieplan.
Correspondentieadres:

Dr. P.M. Boendermaker, UMCG, Wenckebach Instituut, Hanzeplein 1, 9700 RB Groningen.

Email: p.m.boendermaker@wenckebach.umcg.nl

\section{Wetenschappelijke Papers}

\section{Tijdsbesteding van coassistenten en perceptie van de leeromgeving}

\section{E.A. van Hell, J.B.M. Kuks, M.T. van Lohuizen, J. Cohen-Schotanus}

Probleemstelling: De kwaliteit van de leeromgeving is van invloed op de tevredenheid, prestaties en het succes van studenten en daarmee op het leren van coassistenten. ${ }^{1}$ Onbekend is of de feitelijke werkzaamheden van coassistenten samenhangen met hun perceptie van de leeromgeving. Hangt een grotere tijdsbesteding aan onderwijs of begeleiding bijvoorbeeld samen met een betere leeromgeving of kan beter meer tijd worden besteed aan het meelopen met de klinische staf? In deze exploratieve studie wordt onderzocht hoe coassistenten hun tijd in de kliniek besteden en of er een relatie bestaat tussen deze tijdsbesteding en de perceptie van de leeromgeving.

Methode: Aan 322 vijfde- en zesdejaars coassistenten, werkzaam in zeven ziekenhuizen,

Tabel Tijdregistratie

\begin{tabular}{lccc}
\hline Werkzaamheden & Tijd & $(\%)$ & r \\
\hline Zelfstandig uitgevoerde consulten & $0: 56$ & $(12)$ & $-.09^{*}$ \\
Overige zelfstandig uitgevoerde & & $(11)$ & -.16 \\
werkzaamheden & $0: 53$ & $(40)$ & $.23^{*}$ \\
Meelopen/meekijken met klinische staf & $3: 13$ & $(6)$ & .06 \\
Begeleide activiteiten & $0: 30$ & $(10)$ & .13 \\
Bijwonen van besprekingen & $0: 50$ & $(8)$ & $.21^{*}$ \\
Zelfstudie & $0: 41$ & $(6)$ & .06 \\
Onderwijs & $0: 28$ & $(7)$ & -.09 \\
'Verloren' (bijvoorbeeld door wachten) & $0: 32$ & & \\
\hline Totaal & $8: 02$ & &
\end{tabular}


werd gevraagd gedurende twee weken dagelijks te registreren hoeveel tijd zij besteden aan verschillende werkzaamheden (tabel). Daarnaast beoordeelden zij hun leeromgeving door middel van de Postgraduate Hospital Educational Environment Measure (PHEEM). De PHEEM bestaat uit 40 vragen en meet de gepercipieerde kwaliteit van de leeromgeving als één dimensie op een vijf-punts Likertschaal (1 negatief oordeel, 5 positief oordeel). ${ }^{2}$ Berekend werden de gemiddelde tijd die per dag besteed werd aan de werkzaamheden en de invloed van deze tijdsbesteding op de totaalscore op de PHEEM (multipele regressie analyse).

Resultaten: Gemiddeld werkten de 142 (respons $44 \%$ ) coassistenten bijna acht uur per dag. Ruim drie uur werd besteed aan het meelopen en meekijken met de klinische staf, één uur aan het zelfstandig verrichten van consulten en ongeveer een half uur per dag ging verloren (tabel). Coassistenten beoordeelden hun omgeving overwegend positief $(\mathrm{M}=147.6$, $\mathrm{SD}=18.2$ ). De tijd die besteed werd aan zelfstandig uitgevoerde consulten en meelopen/meekijken met klinische staf beïnvloeden de PHEEM-score positief (tabel).

Conclusie: Met acht uur per dag werkt de gemiddelde coassistent binnen de grenzen van de ArbeidsTijdenWet. Dit betekent tegelijkertijd dat een deel van de studenten meer dan acht uur per dag werkt. Opvallend genoeg blijkt de tijdsbesteding aan onderwijs niet samen te hangen met een hogere gepercipieerde kwaliteit van de leeromgeving. Onbekend is of de door coassistenten gepercipieerde kwaliteit van de leeromgeving een reflectie is van daadwerkelijke leerzaamheid van deze omgeving. Onderzocht zal moeten worden wat het relatieve belang is van de (duur van de) werkzaamheden voor de (gepercipieerde) leerzaamheid van het coassistentschap.

\section{Literatuur}

1. Genn JM. AMEE Medical Education Guide No. 23 (part 2): Curriculum, environment, climate, quality and change in medical education - a unifying perspective. Med Teach 2001;23:445-54.
2. Boor K, Scheele F, Van der Vleuten CPM, Scherpbier AJJA, Teunissen PW, Sijtsma K. Psychometric properties of an instrument to measure the clinical learning environment. Med Educ 2007;41:92-9.

Correspondentieadres:

Drs. E.A. van Hell, CIOMO, UMCG/RUG, A. Deusinglaan 1, 9713 AV Groningen.

\section{Hoe klinische opleidingsklimaten verschil- len: een gecombineerde kwantitatieve en kwalitatieve studie}

\section{K. Boor, E.M.E. Breejen, F. Scheele,} P.W. Teunissen, C.P.M. van der Vleuten,

\section{A.J.J.A. Scherpbier}

Probleemstelling: In de literatuur wordt regelmatig beschreven dat er verschillen bestaan tussen stageplaatsen met betrekking tot bijvoorbeeld het leeraanbod of satisfactie van coassistenten. Over verschillen tussen klinische opleidingsklimaten, een belangrijke indicator van de kwaliteit van een opleiding, is binnen medisch-onderwijskundige literatuur nog weinig bekend. Werkplek leren literatuur geeft wel enkele aanwijzingen hoe context het leren beïnvloedt. In deze studie hebben we onderzocht of het klinisch opleidingsklimaat van diverse afdelingen meetbaar van elkaar verschilt en, zo ja, waarin die afdelingen van elkaar verschillen.

Methode: Er is gekozen voor een combinatie van kwantitatief en kwalitatief onderzoek. Allereerst hebben coassistenten van 11 afdelingen Verloskunde \& Gynaecologie een 40-item vragenlijst over het opleidingsklimaat (de PHEEM $^{1}$ ) ingevuld. Analyse van uitkomsten gebeurde met one-way ANOVA analyse en Post-hoc testen. Vervolgens is een kwalitatieve 'case-study' gedaan op de twee afdelingen die kwantitatief het meest verschilden. Per afdeling zijn individuele semi-gestructureerde interviews afgenomen tot saturatie werd bereikt. De interviews zijn volledig uitgeschreven en geanalyseerd. De tekst werd eerst 'open' geco- 
deerd, waarna gezocht is naar onderliggende (sub)categorieën.

\section{Resultaten:}

Kwantitatief: 154 coassistenten vulden de PHEEM in. Er bleken significante verschillen $(p<0.05)$ te bestaan tussen de totaalscores van enkele afdelingen (range 3.52-4.31)

Kwalitatief: 7 coassistenten per afdeling zijn geïnterviewd. Hun antwoorden bleken te passen binnen drie hoofdcategorieën.

Participatie: Op de ene afdeling heerste een traditie waarin het vanzelfsprekend was dat coassistenten aan verschillende werkzaamheden deelnamen, terwijl hier op de andere afdeling nauwelijks aandacht voor bestond.

Afdelingskenmerken: Er bestonden verschillen met betrekking tot onder andere hun begeleiding en in hoeverre hun status als coassistent werd herkend. Op beide afdelingen heerste volgens de coassistenten een goede sfeer.

Interactie coassistent - afdeling: Alle coassistenten probeerden door een pro-actieve houding het beloop van het coschap positief te beïnvloeden. De ene afdeling bleek hier meer ontvankelijk voor dan de andere: op de minder goed scorende afdeling bleek het moeizaam te participeren. Coassistenten met veel doorzettingsvermogen bleken uiteindelijk ook daar in staat tot enige participatie, maar moesten hier wel veel moeite voor doen.

Conclusie: Het klinisch opleidingsklimaat verschilt tussen afdelingen. Verschillen zitten in participatie en afdelingskenmerken. Het verschil leidt tot ander gedrag bij de coassistenten op deze afdelingen. De gevonden resultaten worden ondersteund door bevindingen van Fuller \& Unwin. ${ }^{2} \mathrm{Zij}$ beschrijven een studie onder 'apprentices' in Groot-Brittannië waar zij twee benaderingen van participatie herkennen: een 'expanded approach' en een 'restrictive approach'. Dit komt overeen met de hier beschreven bevindingen. Het herkennen van deze benaderingen kan afdelingen sturing geven in hoe zij hun opleidingsklimaat kunnen veranderen. Daarnaast draagt deze informatie bij aan een verdere conceptualisering van het begrip 'klinisch opleidingsklimaat'.

\section{Literatuur}

1. Boor K, Scheele F, van der Vleuten CP, Scherpbier AJ, Teunissen PW, Sijtsma K. Psychometric properties of an instrument to measure the clinical learning environment. Med Educ 2007;41:92-99.

2. Fuller A, Unwin L. Learning as apprentices in the contemporary UK workplace: creating and managing expansive and restrictive participation. $\mathrm{J}$ Educ Work 2003;16:407-26.

Correspondentieadres:

Drs. K. Boor, Sint Lucas Andreas Ziekenhuis, Medisch onderwijs, Postbus 9243, 1007AE Amsterdam. E-mail: K.Boor@slaz.nl

\section{Kenmerken van reflectiestimulerende schriftelijke feedback in portfolio's}

\section{H. Dekker, J. Schönrock-Adema, J. Cohen- Schotanus}

Probleemstelling: Portfolio's worden vaak gezien als het onderwijsmiddel om reflectie van studenten te bevorderen. Implementatie biedt echter geen garantie dat studenten daadwerkelijk leren reflecteren ${ }^{1}$. Er zijn verschillende voorwaarden voor succesvol reflectief gebruik van portfolio's. Eén daarvan is het coachen van studenten bij het leren reflecteren. Een onderdeel van dit coachen is het geven van feedback op portfolio's. Er is weinig bekend over de kwaliteit van schriftelijke feedback op portfolio's en aan welke kenmerken deze feedback moet voldoen om reflectie te stimuleren. Daarom richt deze studie zich op de volgende vragen:

1.Welke schriftelijk feedbackcommentaren stimuleren reflectie van studenten?

2. Welke dimensies zijn te herkennen in schriftelijke feedbackcommentaren?

Methode: Dit onderzoek is gebaseerd op schriftelijke feedbackcommentaren uit een steekproef van 90 reflectieverslagen. Deze verslagen zijn afkomstig uit eerste- en tweedejaars portfolio's (studiejaar 2004/2005). Een expertpanel van 21 deelnemers aan een reflectieconferentie heeft op een 5-punts Likertschaal aangegeven in hoeverre de schriftelijke feedbackcommentaren reflectie stimuleren. Een feedbackcommentaar werd als stimulerend beoordeeld wanneer mini- 
maal 75\% van de experts het als zodanig karakteriseerde $(+$ en ++$)$. Voor niet-stimulerende feedbackcommentaren gold het tegenovergestelde. Voor de tweede onderzoeksvraag hebben 23 onderwijskundigen en docenten de feedbackcommentaren in categorieën gesorteerd. Op deze sorteringen is een homogeniteitsanalyse $^{2}$ (HOMALS, SPSS 12) uitgevoerd om onderliggende dimensies vast te stellen.

Resultaten: 43 reflectieverslagen waren voorzien van schriftelijke feedbackcommentaren. Elf feedbackcommentaren werden gekwalificeerd als reflectiestimulerend en zes als nietreflectiestimulerend. De overige 26 commentaren lieten een diffuus beeld zien. De HOMALS-analyse leidde tot drie dimensies: 1) formulering (vraag versus constatering), 2) inhoud (gericht op professionele ontwikkeling versus gericht op lay-out/structuur/hiaten en 3) toon (positief versus negatief). De combinatie van de resultaten op beide onderzoeksvragen liet zien dat de elf reflectiestimulerende feedbackcommentaren allemaal als vraag waren geformuleerd (dimensie 1) en meestal betrekking hadden op het professionele ontwikkeling van de student (dimensie 2). Daarentegen bleken de als niet-reflectiestimulerend gekwalificeerde feedbackcommentaren als constatering te zijn geformuleerd (dimensie 1) en meestal betrekking te hebben op layout/structuur/hiaten (dimensie 2). De derde dimensie (toon) differentieerde niet tussen wel/niet reflectie stimulerende commentaren. Conclusie: Geconcludeerd kan worden dat bij portfolio's schriftelijke feedback te karakteriseren is op drie dimensies. Feedback in vraagvorm, en gericht op professionele ontwikkeling, lijkt reflectie het meest te stimuleren. Gezien het feit dat in de helft van de gevallen studenten sowieso geen feedback kregen en het feit dat slechts weinig feedbackcommentaren als reflectiestimulerend werden beoordeeld, kan worden gesteld dat docenten beter moeten worden getraind in het geven van reflectiestimulerende schriftelijke portfoliofeedback.

\section{Literatuur}

1. Pearson DJ, Heywood P, Portfolio use in general practice vocational training: a survey of GP registrars. Med Educ 2004;38:87-95.

2. Gifi, A. Non linear multivariate analysis. Chicester: Wiley 1990

Correspondentieadres:

Drs. H Dekker, UMCG, CIOMO, A. Deusinglaan 1, 9713 AV Groningen.

\section{De invloed van diepgaand leren en intel- lectualiteit op de resultaten van open en gesloten-boek toetsen}

M. Heijne-Penninga, J.B.M. Kuks, W.H.A. Hofman, J. Cohen-Schotanus

Inleiding: Het medisch kennisdomein breidt zich in hoog tempo uit. Een manier om hier in een medisch curriculum mee om te gaan, is het toevoegen van open-boek toetsen aan het examenprogramma. ${ }^{1}$ Toetsresultaten kunnen worden beïnvloed door leerstrategie en persoonskenmerken. Volgens de literatuur zouden studenten met een diepgaande leerstrategie beter moeten presteren dan studenten met een minder diepgaande leerstrategie. Een persoonskenmerk dat de resultaten mogelijk positief beïnvloedt is 'intellectualiteit'. Intellectualiteit is het blijk geven van vlugheid van begrip en graag bezig zijn met inspannende cognitieve problemen. ${ }^{2}$ In deze studie is de relatie onderzocht tussen mate van diepgaand leren, intellectualiteit en open of gesloten-boek toetsresultaten.

Methode: Het onderzoek werd uitgevoerd in 2005/2006 onder tweedejaars studenten Geneeskunde $(n=188)$ die gewend zijn aan open en gesloten-boek toetsen. Van deze groep zijn de scores op twee open en twee gesloten-boek toetsen verzameld. Diepgaand leren werd gemeten met de gevalideerde vragenlijst Diepgaande Leerstofverwerking bestaande uit de schalen: Kritisch Lezen (KL), 9 items zoals "Als ik een tekst bestudeer volg ik aandachtig de argumentatie"; Structuur Zoeken (SZ), 7 items 
zoals "Als ik een tekst bestudeer besteed ik aandacht aan titels en tussenkopjes"; en Context Verbreden (CV), 8 items zoals "Als ik een tekst bestudeer bedenk ik zelf voorbeelden”. Intellectualiteit werd gemeten met een gevalideerde vragenlijst met drie schalen: Intellectuele Apathie (INAP), 17 items zoals "Als een oplossing lijkt te werken, hoef ik niet te weten hoe of waarom die precies werkt"; Need for Cognition (NCOG), 10 items zoals "Ik hou van situaties waarin veel nagedacht moet worden"; en Cultuur (CULT), 3 items zoals "Ik heb een levendige fantasie". ${ }^{2}$ In beide vragenlijsten moeten de items op een vijfpunt-Likertschaal worden beantwoord. De samenhang tussen leerstrategie, intellectualiteit en toetsscores is bepaald met een padanalyse met behulp van het programma Lisrel.

Resultaten: Een hogere score voor intellectualiteit leidt tot een hogere score voor de openboek toets (padcoëfficiënt $=.28, \mathrm{p}<.05$ ), dit geldt veel minder sterk voor de gesloten-boek toets (padcoëfficiënt $=.07, \mathrm{p}<.01$ ) Diepgaand leren heeft geen invloed op de toetsscores (padcoëfficiënt open-boek $=.02, \mathrm{p}=.45$; padcoëfficiënt gesloten-boek $=-.04, \mathrm{p}=.06$ ).

Conclusie: Intellectualiteit is een houding die verwacht mag worden van academische opgeleide studenten, open-boek toetsen lijken hierop aan te sluiten. Noch bij open-boek toet- sen, noch bij gesloten-boek toetsen wordt een verband gevonden tussen diepgaand leren en resultaat. Deze uitkomst komt overeen met vergelijkbare (inter)nationale onderzoeken van recente datum. Langzamerhand rijst de vraag of diepgaand leren nog steeds het meest wenselijk is in de huidige tijd, met de huidige generatie studenten. Verder onderzoek hieromtrent is gewenst.

\section{Literatuur}

1. Heijne-Penninga M, Kuks JBM, SchönrockAdema J, Snijders TAB, Cohen-Schotanus J. Open-book tests to complement assessment-programmes: analysis of open and closed-book tests. Advances in Health Sciences Education 2006; [epublication ahead of print].

2. Schouwenburg HC. Handleiding bij INTEL'95: een test voor Intellectualisme. Studie Ondersteuning. Rijksunivesiteit Groningen 1996.

Correspondentieadres:

Drs. M. Heijne-Penninga, UMCG, Onderwijsinstituut, A. Deusinglaan 1, 9713 AV Groningen.

Email:m.penninga@med.umcg.nl 